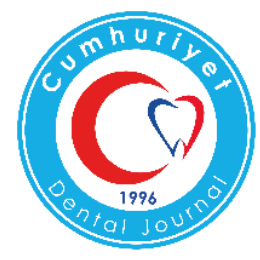

\title{
THE COMPARISON OF SHEAR BOND STRENGHT OF DIFFERENT BULK-FILL COMPOSITES TO A BIOACTIVE DENTINE SUBSTITUTE
}

\author{
Farklı Bulk-Fill Kompozitlerin Bir Bioaktif Dentin Substratına Makaslama \\ Bağlanma Dayanımlarının Karşılaştırılması
}

\author{
Murat ÜNAL
}

$\begin{array}{ll}\text { Makale Kodu/Article Code } & : 433716 \\ \text { Makale Gönderilme Tarihi } & : 13.06 .2018 \\ \text { Kabul Tarihi } & : 09.07 .2018\end{array}$

\section{ABSTRACT}

Objective: The aim of this research was to compare shear bond strength(SBS) of various bulk-fill composites (BFC) to Biodentine(BD) with different time intervals.

Materials and Methods: 300 cyclindrical acrylic blocks with a hole (4 $\mathrm{mm}$ diameter a $2 \mathrm{~mm}$ height) were prepared. The holes were filled with BD and after bonding application, 5 different BFC groups (Tetric EvoCeram Bulk Fill, Filtek Bulk Flow, Beautifil Bulk, Filtek Bulk Fill Posterior and SDR) were divided into 10 main groups in $2 \mathrm{~mm}$ and $4 \mathrm{~mm}$ height, and these 10 main groups were divided into 3 subgroups according to three different waiting times (12 min, 24 hour and 2 week). After then, SBSs measured and the fractured surfaces were examined. Statistical analyzes were performed with Kolmogorov-Simirnov, Tukey HSD and One-way ANOVA tests.

Results: There was found statistically significant difference in all BFC groups between 12 minutes, 24 hours and 2 weeks $(\mathrm{p}<0.05)$. Significant differences were found between the $2 \mathrm{~mm}$ and $4 \mathrm{~mm}$ Filtek Posterior BFCs $(\mathrm{p}<0.05)$. However, there was not significant differences in the other BFC groups ( $>0.05)$.

Conclusion: In all BFC groups, there was significant difference found between the groups waited for 12 min and,24 $\mathrm{h}$ and 2 weeks. In clinically, we may prefer to use $\mathrm{BFC}$ at a height of $4 \mathrm{~mm}$, onto BD with after 1 day of waiting time

Keywords: Bulk-fill Composite, Biodentine, Shear Bond Strength

\section{Öz}

Amaç: Araştırmanın amacı farklı Bulk-fill kompozitlerin (BFK) Biodentine (BD) farklı zaman aralıklarında bağlantı dayanımlarını karşılaştırmaktır.

Gereç ve Yöntemler: Çalışmada, 300 adet akrilik blok, ortası boşluk olacak (2mm kalınlık ve $4 \mathrm{~mm}$ yükseklikte) şekilde hazırlanmıştır. Bu boşluk kısım, BD ile doldurulmuş ve 5 farklı BFK, BD üzerine $2 \mathrm{~mm}$ ve $4 \mathrm{~mm}$ yüksekliklerde (her bir grup 10 örnekten oluşacak şekilde) bağlanarak, üç farklı bekleme süresine göre 3 alt gruba ayrılmıştır (12 dk., 24 sa ve 2 hafta). Daha sonra bağlantı dayanım değerleri ölçüldü ve kırık yüzeyler incelendi. İstatistiksel analizler Kolmogorov-Simirnov, Tukey HSD ve One-way ANOVA testleri ile yapıldı.

Bulgular: Tüm BFK gruplarında 12 dakika, 24 saat ve 2 hafta bekletilmiş gruplar arasında anlamlı fark bulundu (p<0,05). $2 \mathrm{~mm}$ ve $4 \mathrm{~mm}$ Filtek Posterior BFK'ler arasında anlamlı fark bulunurken $(\mathrm{p}<0,05)$, diğer BFK gruplarında anlamlı farklılık bulunmadı $(\mathrm{p}>0,05)$.

Sonuç: Tüm BFC gruplarında 12 dakika, 24 saat ve 2 hafta bekletilmiş gruplar arasında anlamlı fark bulundu. Klinik olarak BD üzerine $4 \mathrm{~mm}$ yükseklikte BFK uygulaması yapılacaksa, 1 gün beklemeyi tercih edebiliriz.

Anahtar Kelimeler: Bulk-fill kompozit, Biodentine, Makaslama Bağlantı Dayanımı 


\section{INTRODUCTION}

Vital pulp treatments includes all treatments that reduce pulp injuries by protecting the pulp from toxic, mechanical and thermal effects, which is aimed to treat reversible pulp injuries and to cover the pulp with a suitable material; and also, trigger reperative dentin formation. ${ }^{1}$ For this purpose, a wide variety of materials such as calcium hydroxide, zinc-oxide ogenol, formocresol, gluteraldehyde, bonding systems, collagen fibers and cytokines have been used to date. ${ }^{2,3}$ Calcium hydroxide, among these materials, is the most commonly used due to having properties as the induction of reperative dentin formation, being antibacterial, cheap and easy to manipulate. ${ }^{2}$ However, calcium hydroxide has a great deal of disadvantages such as; resorption over time, microleakage into these resorbed areas, fractures and cracks during restorative procedures due to being thin and weak, causing necrotic tissue because of its high alkalinity, causing necrosis and degeneration in the pulp, leading to internal resorption in direct pulp capping and amputation treatments. ${ }^{4,5}$ Due to these mentioned factors, new and alternative substances were needed in vital pulp treatments.

MTA has been accepted as a reference material for pulp treatments because of its high success rates (90-100\%) in clinical, radiological and histopathological studies. Nevertheless, despite its positive properties, MTA has the disadvantages of long hardening time, high resolution throughout the hardening process, and the coloring potential of tooth tissues and difficult manipulation. ${ }^{6}$ In order to overcome these drawbacks, various calcium silicate cements have been developed, and Biodentine (BD) is the most recent of these cements.

BD contains tri- and dicalcium silicate as main materials, calcium carbonate as the filler, and zirconium dioxide as the radio-opacity provider. $^{7,8}$ Liquid form consists of distilled water, calcium chloride and a water-soluble polymer. Calcium chloride acts as an accelerator to expedite the hardening process of the material. ${ }^{9}$ The mixing of BD's powder and liquid allows the ionic exchange and polymerization leading to the formation of a solid network over time. The product of the reaction consists of a cemental phase containing tricalcium silicate, and a radio-opasity provider phase containing zirconium oxide. Reported that calcium carbonate acts as a nucleation site for formation of the reaction, thereby increasing hydration and producing more dense microstructure. $^{7,10}$ The most important advantages of BD over MTA are easier clinical use, high viscosity, caused less discoloration, short curing time (12 min) and better physical properties. ${ }^{11}$ However, when literature review was performed, it was obvious that shear-bond strenght(SBS) values of $\mathrm{BD}$ to resin-based materials were found to increase more after 1 day. ${ }^{12}$

In nanocomposites, when the thickness of the resin composite material placed in the cavity exceeds $2 \mathrm{~mm}$, reported in studies that it adversely affects the polymerization, and so the physical properties and the clinical life span of the restoration. ${ }^{13-16}$ For this reason, BFC materials have been developed recently in order to apply composites to cavity in large quantities, and to reduce the application time. ${ }^{17}$ These BFCs have advantages of lower viscosity than conventional resin composites, and less polymerization shrinkage than flowable composites. ${ }^{18-20}$ Bis-GMA, aliphatic urethane dimethacrylate, partial aromatic dimethacrylate or highly branched methacrylate monomers are added to the organic matrix portion of the BFCs. This addition to the matrix and monomer structure reduces the polymerization shrinkage of the material by $70 \%$, and improves the translucency of the resin, resulting in deeper stratification of the light required for polymerization, and increase in the conversion rate. ${ }^{14}$ BFCs shorten the working time because they are applied in bulks to the cavity at once. Thus, it is known that they increase the comfort of both dental physicians and patients. 
In this research, we examined the SBS values of these two different ( $2 \mathrm{~mm}$ and $4 \mathrm{~mm}$ ) thicknesses of BD and we aimed to compare SBSs of 5 different BFCs placed at two different thicknesses ( $2 \mathrm{~mm}$ and $4 \mathrm{~mm}$ ) after 3 different time periods of BD retention (12 $\mathrm{min}, 24 \mathrm{~h}$ and 14 days).

\section{MATERIALS AND METHODS}

\section{Preparation of Acrylic Blocks;}

A total of 300 acrylic blocks containing a central hole with a $4 \mathrm{~mm}$ diameter a $2 \mathrm{~mm}$ height were prepared. Biodentine (Septodent, Saint-Maur-des-Fosses Cedex, France) was mixed according to the manufacturer's instructions (as described below) and acrylic blocks were fully filled with Biodentine (BD).

\section{Placement of BD into Acrylic Blocks;}

BD was prepared according to the manufacturer's directions as explained below;

-The capsule containing BD powder was opened and placed on the capsule carrier which was also included in the box,

-Later its own the liquid containing pipette was opened, and 5 drops were poured into the capsule,

-Powder capsule was closed back and placed in amalgamator (ADM 9002, MedidentGbR, Treffurt, Germany) to mix, and stirred for 30 seconds,

-After stirring, the capsule was opened to ensure that BD was mixed homogenously.

-BD in the capsule was placed into the $4 \mathrm{~mm}$ diameter spaces on acrilic blocks by plastic spatulas, which were included in the box of the product, and was gently condensed. All the samples in the study, BD was placed into acrylic blocks by being prepared as mentioned above.

\section{Separation of Bulk-Fill Composites(BFCs) into Groups;}

Single Bond Universal [(SBU) (3M Espe, St. Paul, MN, USA)] adhesive system was applied to the BD surface of samples prepared in total with Self-Etch (SE) technique as described below in accordance with the user's instructions after 3 different waiting times (12 minutes, 24 hours and 2 weeks) (all specimens stored at $37^{\circ} \mathrm{C}$ with $100 \%$ humidity during the waiting time).

\section{SBU-SE application;}

The adhesive was applied to the BD surface with the help of a disposable bond brush for 20 seconds of scrubbing, and gently air-dried for 5 seconds by using the air-water spray until no movement on the adhesive occurred. Polymerization was achieved by irradiating LED curing light (Elipar S10, 3M ESPE, St. Paul, MN, USA) for 10 seconds.

After bonding application, 5 different BFC [TetricEvo (TE), Filtek Bulk Flow (FF), BEAUTIFIL(BE), Filtek Bulk Fill Posterior (FP) and SDR)] groups were divided into 10 main groups in $2 \mathrm{~mm}$ and $4 \mathrm{~mm}$ thickness, and these 10 main groups were divided into 3 subgroups ( $\mathrm{n}=10$ was accepted in all groups). (Table 1)

The each of 10 experimental groups were divided into 3 subgroups as follows in table 1 .

Table 1: Classification of experimental test groups
\begin{tabular}{|l|l|l|l|l|l|l|}
\hline \multirow{2}{*}{$\begin{array}{c}\text { Thickness } \\
\text { Waiting } \\
\begin{array}{c}\text { TtiTipes } \\
\text { Composites }\end{array}\end{array}$} & $\begin{array}{l}\text { 12 } \\
\text { Min }\end{array}$ & $\begin{array}{l}24 \\
\text { Hours }\end{array}$ & $\begin{array}{l}2 \\
\text { Weeks }\end{array}$ & $\begin{array}{l}\text { Min } \\
12\end{array}$ & $\begin{array}{l}24 \\
\text { Hours }\end{array}$ & $\begin{array}{l}2 \\
\text { Weeks }\end{array}$ \\
\hline $\begin{array}{l}\text { Tetric Evo } \\
\text { (TE) }\end{array}$ & G1a & G1b & G1c & G2a & G2b & G2c \\
\hline $\begin{array}{l}\text { Filtek Bulk } \\
\text { Flow (FF) }\end{array}$ & G3a & G3b & G3c & G4a & G4b & G4c \\
\hline $\begin{array}{l}\text { Beautiful } \\
\text { (BE) }\end{array}$ & G5a & G5b & G5c & G6a & G6b & G6c \\
\hline $\begin{array}{l}\text { Filtek Bulk } \\
\text { Fill } \\
\text { Posterior } \\
\text { (FP) }\end{array}$ & G7a & G7b & G7c & G8a & G8b & G8c \\
\hline SDR & G9a & G9b & G9c & G10a & G10b & G10c \\
\hline
\end{tabular}


All BFC materials were placed on a BD at the heights stated above, with the aid of a Teflon mold, $2 \mathrm{~mm}$ in diameter, $2 \mathrm{~mm}$ and $4 \mathrm{~mm}$ in heights. BFC materials in all the groups were polymerized by irradiating with LED light curing device for $40 \mathrm{sec}$. All materials used in this research shown in Table 2.

Table 2. The materials used in this study

\begin{tabular}{|c|c|c|c|}
\hline $\begin{array}{c}\text { Brand } \\
\text { Name(Manufacturer) }\end{array}$ & \begin{tabular}{|c|} 
Type of resin \\
Bulk fill \\
composite
\end{tabular} & $\begin{array}{l}\text { Matrix } \\
\text { Composition }\end{array}$ & $\begin{array}{l}\text { Inorganic filler content } \\
\quad(\mathbf{w t} \%, \mathrm{vol} \%)\end{array}$ \\
\hline $\begin{array}{l}\text { Tetric EvoCeram Bulk Fill } \\
\text { (Ivoclar Vivadent, } \\
\text { Schaan, Lichtenstein) } \\
\end{array}$ & \begin{tabular}{|l}
$\begin{array}{l}\text { High viscosity } \\
\text { bulk-fill resin } \\
\text { composite }\end{array}$ \\
\end{tabular} & \begin{tabular}{|l|} 
UDMA, \\
Bis-EMA, \\
EBPADMA \\
\end{tabular} & $\begin{array}{l}\text { Barium aluminium silicate } \\
\text { glass, ytterbium triluoride, } \\
80.0 \mathrm{wt} \%, 61.0 \text { vol } \%\end{array}$ \\
\hline $\begin{array}{l}\text { Filtek Bulk Flow } \\
\text { (3M ESPE St Paul, MN, } \\
\text { USA) }\end{array}$ & \begin{tabular}{|l|}
$\begin{array}{l}\text { Low viscosity } \\
\text { bulk-fill resin } \\
\text { composite }\end{array}$ \\
\end{tabular} & \begin{tabular}{|l} 
Bis-GMA, \\
Bis-EMA, UDMA \\
\end{tabular} & $\begin{array}{l}\text { Silane treated ceramic, } \\
\text { ytterbium fluoride filler, } \\
64.5 \mathrm{wt} \%, 42.5 \mathrm{vol} \%\end{array}$ \\
\hline $\begin{array}{c}\text { Beautifil Bulk } \\
\text { ( SHOFU Kyoto, Japan ) }\end{array}$ & \begin{tabular}{|l}
$\begin{array}{l}\text { High viscosity } \\
\text { bulk-fill } \\
\text { giomer }\end{array}$ \\
\end{tabular} & \begin{tabular}{|l} 
Bis-GMA, UDMA, \\
Bis-MPEPP, \\
TEGDMA \\
\end{tabular} & $\begin{array}{l}\text { Fluoro-silicate glass, } \\
87.0 \mathrm{wt} \%, 74.5 \text { vol } \%\end{array}$ \\
\hline $\begin{array}{l}\text { Filtek Bulk Fill Posterior } \\
\text { (3M ESPE St Paul, MN, } \\
\text { USA) }\end{array}$ & 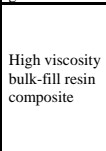 & $\begin{array}{l}\text { AromaticUDMA, } \\
\text { UDMA, } \\
1,12 \text {-dodecane- } \\
\text { dimethacrylate }\end{array}$ & $\begin{array}{l}\text { non-agglomerated/non- } \\
\text { aggregated } \\
\text { silica filler, non- } \\
\text { aggglomerated/non-aggregated } \\
\text { filler, aggregated } \\
\text { zirconia/silica cluster filler, } \\
\text { ytterbium trifluoride filler, } \\
76.5 \mathrm{wt} \%, 58.4 \text { vol\% } \\
\end{array}$ \\
\hline $\begin{array}{l}\text { SDR } \\
\text { (DENTSPLY Caulk, } \\
\text { Milford, DE, USA) }\end{array}$ & $\begin{array}{l}\text { Low viscosity } \\
\text { bulk-fill resin } \\
\text { composite }\end{array}$ & \begin{tabular}{|l} 
Modified UDMA, \\
Bis-EMA, \\
TEGDMA
\end{tabular} & $\begin{array}{l}\text { Barium-alumino-fluoro- } \\
\text { silicate } \\
\text { glass, Strontium } \\
\text { alumino-fluoro-silicate glass, } \\
68.0 \mathrm{wt} \%, 44.0 \text { vol } \%\end{array}$ \\
\hline & \multicolumn{3}{|c|}{ Composition } \\
\hline $\begin{array}{l}\text { Single Bond Universal ( } 3 \mathrm{M} \\
\text { ESPE, St. Paul, MN, USA) }\end{array}$ & \multicolumn{3}{|c|}{$\begin{array}{l}\text { 10-MDP phosphate monomer, Vitrebond copolymer, HEMA, BISGMA, } \\
\text { dimethacrylate resins filler, silane, initiators, ethanol, water }\end{array}$} \\
\hline $\begin{array}{l}\text { Biodentine (Septodent, } \\
\text { Saint-Maur-des-Fosses } \\
\text { Cedex, France) }\end{array}$ & \multicolumn{3}{|c|}{$\begin{array}{l}\text { Powder: Tri-calcium silicate, di-calcium silicate, calcium carbonate and } \\
\text { oxide filler, riron oxide, zirconium oxide radiopacifier } \\
\text { Liquid: calcium chloride acceleratorhydrosoluble polymer water reducing } \\
\text { agent. }\end{array}$} \\
\hline
\end{tabular}

\section{Shear Bond Strength (SBS) Test}

The polymerized specimens were stored in $100 \%$ relative humidity at $37^{\circ} \mathrm{C}$ for 24 hours. For SBS testing, the specimens were secured in a holder placed on the platen of the testing machine and then sheared with a knife-edge blade on a universal testing machine (LF Plus, LLOYD Instruments, AmatekInc, UK) at a cross head speed of $1.0 \mathrm{~mm} / \mathrm{min}$. SBS in Mpa was calculated by dividing the peak load at failure with the specimen surface area.

\section{Fracture Analysis}

Fractured test specimens were examined under a stereomicroscope (Stemi DV4: Carl Zeiss, Gottingen, Germany) at a magnification of $25 \times$. Specimen fractures were classified as follows: cohesive failure within BD or composite, adhesive failure that occurred at the BDcomposite interface; or mixed failure when 2 modes of failure happened simultaneously (Table 4). Fracture analysis was performed by a single observer who was completely uninformed about the experimental groups. In figure 1 are shown the adhesive, cohesive and mix fracture pictures.

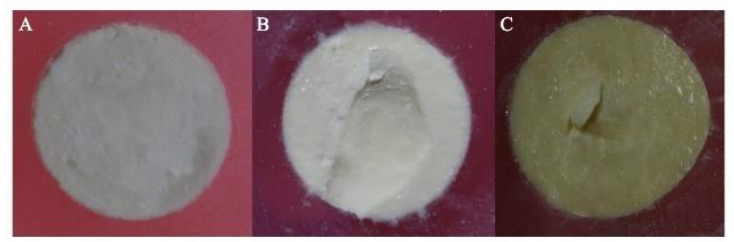

Fig 1. Steriomicroscopic imaging of the failure modes. (A) Adhesive failure (B) Cohesive failure (C) Mix failure.

For the SEM analyses, samples randomly selected from the 12-min, 24-hour and 2 week groups of the failure specimens. The failure surfaces were sputter-coated with gold using a SputterCoater, and specimens were analyzed with an SEM [TESCAN MIRA 3 XMU (Brno, Czech Republic)].

In statistical method, the data, obtained in our study, were loaded with SPSS 22.0 program, and determined by KolmogorovSmirnov test whether the data are in normal distribution. In the research, t-test (IndependentSamples t-test) was used in twogroup comparisons, yet ANOVA (F) test was more preferable for more than 2 group comparisons to determine any possible differences between groups.

Thereafter, the Tukey HSD multiple comparison test was applied to determine any further differences between the groups. The significance level was set at $\mathrm{p}<0.05$ for all the tests.

\section{RESULTS}

In both $2 \mathrm{~mm}$ and $4 \mathrm{~mm}$ groups of TE, FF, BE, FP, and SDR (Table 2), BFC groups, the fracture values obtained from $\mathrm{BD}$ awaited for $12 \mathrm{~min}, 24 \mathrm{~h}$ and $2 \mathrm{w}$ are statistically compared; the difference between the groups of $12 \mathrm{~min}$ and $24 \mathrm{~h}$ and 2 weeks was statistically significant $(\mathrm{p}<0.05)$, yet the difference between the groups of BD kept for $24 \mathrm{~h}$ and $2 \mathrm{w}$ was statistically insignificant $(p>0.05)$. Similarly, effects of thickness differences $(2 \mathrm{~mm}$ and $4 \mathrm{~mm}$ ) on fracture values of TE (G1 and 2), FF (G3 and 4), BE (G5 and 6), and SDR (G9 and 10) BFCs 
were examined, and the difference between the groups was found to be statistically insignificant $(p>0.05)$, while the difference between the FP (G7 and 8) BFC groups was statistically significant $(\mathrm{p}<0.05)$. (Table 3$)$ All fracture analyzes results are given in Table 4.

Table 3. SBS values [Mean(SD)] between Biodentine and Bulk-fill composites

\begin{tabular}{|c|c|c|c|c|c|c|c|c|c|c|}
\hline$\Leftrightarrow$ & $\begin{array}{c}\text { G1 } \\
\text { (Tetric } \\
\text { evo } \\
2 \mathrm{~mm})\end{array}$ & $\begin{array}{c}\text { G2 } \\
\text { (Tetric } \\
\text { evo } \\
\text { 4mm) }\end{array}$ & $\begin{array}{l}\text { G3 } \\
\text { (FILTEK } \\
\text { FLOW } \\
\text { 2mm) }\end{array}$ & $\begin{array}{c}\text { G4 } \\
\text { (FILTEK } \\
\text { FLOW } \\
4 \mathrm{~mm})\end{array}$ & $\begin{array}{c}\text { G5 } \\
\text { (Beautifil } \\
\text { 2mm) }\end{array}$ & $\begin{array}{c}\text { G6 } \\
\text { (Beautifil } \\
4 \mathrm{~mm})\end{array}$ & $\begin{array}{c}\text { G7 } \\
\text { (FILTEK } \\
\text { POSTERIOR } \\
\text { 2mm) }\end{array}$ & $\begin{array}{c}\text { G8 } \\
\text { (FILTEK } \\
\text { POSTERIOR } \\
4 \mathrm{~mm} \text { ) }\end{array}$ & $\begin{array}{c}\text { G9 } \\
\text { (SDR 2mm) }\end{array}$ & $\begin{array}{c}\text { G10 } \\
\text { (SDR 4mm) }\end{array}$ \\
\hline $12 \min$ & $5,49(0,69)^{\mathrm{a}}$ & $4,31(1,05)^{c}$ & $4,19(1,12)^{\mathrm{e}}$ & $3,62(0,99)^{\mathrm{g}}$ & $4,79(0,62)^{1}$ & $3,92(0,79)^{k}$ & $7,18(0,67)^{\mathrm{m}}$ & $5,91(0,95)^{\circ}$ & $5,65(82)^{\mathrm{r}}$ & $4,93(0,69)^{\mathrm{t}}$ \\
\hline 1 day & $9,81(1,25)^{\mathrm{b}}$ & $8,95(1,28)^{d}$ & $8,77(1,54)^{\mathrm{f}}$ & $7,96(1,43)^{\mathrm{h}}$ & $10,31(0,78)^{\mathrm{J}}$ & $9,24(1,37)^{1}$ & $14,98(2,22)^{\mathrm{n}}$ & $12,68(1,27)^{p}$ & $11,17(1,01)^{\mathrm{s}}$ & $10,15(0,60)^{\mathrm{u}}$ \\
\hline $2 \mathrm{w}$ & $9,50(1,29)^{b}$ & $9,18(1,09)^{d}$ & $7,89(1,04)^{\mathrm{f}}$ & $7,23(1,30)^{\mathrm{h}}$ & $9,73(0,93)^{\mathrm{J}}$ & $8,76(1,00)^{1}$ & $14,18(1,88)^{\mathrm{n}}$ & $11,86(1,44)^{\mathrm{p}}$ & $10,84(0,74)^{\mathrm{s}}$ & $9,82(0,50)^{\mathrm{u}}$ \\
\hline 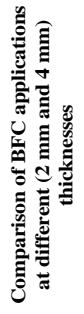 & \multicolumn{2}{|c|}{$\mathrm{p}=0.211$} & \multicolumn{2}{|c|}{$\mathrm{p}=0.260$} & \multicolumn{2}{|c|}{$\mathrm{p}=0.163$} & \multicolumn{2}{|c|}{${ }^{*} \mathrm{p}=0.041$} & \multicolumn{2}{|c|}{$\mathrm{p}=0.178$} \\
\hline
\end{tabular}

*Statistically significant difference within in the bottom row $(\mathrm{p}<0.05)$.

-Shear bond strength values are shown as Mean(SD). All the groups were evaluated separately within themselves and different lower-case letter represents statistical significant difference within each column.

Table 4. Fracture failure types of the groups

\begin{tabular}{|c|c|c|c|c|c|c|c|c|c|c|}
\hline 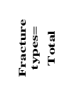 & \begin{tabular}{|c|}
$G 1$ \\
(Tetric \\
ero \\
2 mm) \\
\end{tabular} & \begin{tabular}{|c} 
G2 \\
(Tetric evo \\
4mm)
\end{tabular} & $\begin{array}{c}\text { G3 } \\
\text { (FLLTRK } \\
\text { FLLW 2 mm) }\end{array}$ & $\begin{array}{c}\text { G4 } \\
\text { (FLITEK } \\
\text { FLOW } \\
\text { 4mim) }\end{array}$ & $\begin{array}{c}65 \\
\text { (Beautifll } \\
\text { 2min) }\end{array}$ & $\begin{array}{c}\mathrm{G} 6 \\
\left(\begin{array}{c}\text { (Beautifil } \\
\text { 4mm }\end{array}\right.\end{array}$ & \begin{tabular}{|c} 
G7 \\
(FLLTEK \\
POSTERIOR \\
$2 \mathrm{~mm}$ )
\end{tabular} & \begin{tabular}{|c} 
G8 \\
(fHITRK \\
POSTRRIOR \\
4mm)
\end{tabular} & $\begin{array}{c}\text { G9 } \\
\text { (SDR } 2 \mathrm{~mm})\end{array}$ & $\begin{array}{l}\text { G10 } \\
\text { (SDR } \\
4 \mathrm{~mm})\end{array}$ \\
\hline Adhesire=2 & 1 & 3 & 6 & 4 & 2 & 1 & 3 & 2 & 3 & 4 \\
\hline Conesire=213 & 26 & 21 & 20 & 21 & 25 & 24 & 21 & 21 & 22 & 17 \\
\hline Mir $=44$ & 3 & 6 & 4 & 5 & 3 & 5 & 6 & 7 & 5 & 9 \\
\hline
\end{tabular}

Figure 2 represents SEM images of BFC after waiting times, $12 \mathrm{~min}$ (Fig 2a), $24 \mathrm{~h}$ (Fig 2b) and $2 \mathrm{w}$ (Fig 2c).

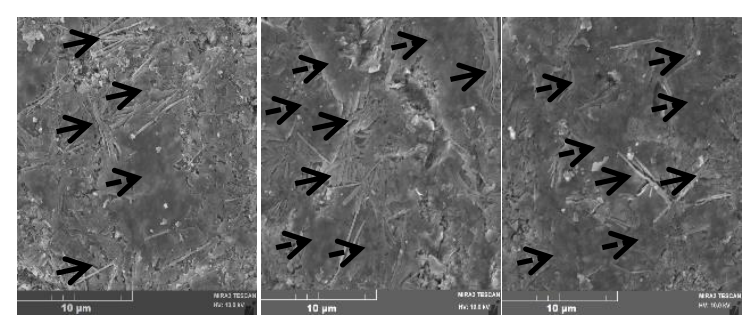

Figure 2. SEM images of Biodentine after waiting times for 12 min.; (a) 12 min., (b) 1 day, (c) 2 week.

As seen from (a) to (c), the polymerizaton increases by cross-linking and surface smoothening. The characteristic polymer surface can be found more at $24 \mathrm{~h}$ and $2 \mathrm{w}$. In Figure 1 (a), the unpolymerized surface is obvious by particle like morphology and some smoothened areas were formed due to the natural quick usability of BD. The unpolymerized regions may be responsible from the low mechanical properties associated with fast degradation for the long term use. The black arrows show the polymerized and crosslinked regions. The smooth areas as seen by dashed arrows decrease the roughness by increasing polymerization time. The unpolymerized regions with high roughness and particle like morphology may also cause faster peeling of the resin and deformation. This may result in differentiation of tooth color and cosmetic problems.

\section{DISCUSSION}

Biodentine (BD) contains tri- and dicalcium silicate as parent materials, calcium carbonate as a filler improving its mechanical properties, and zirconium oxide as a radio-opacity provider. ${ }^{7}$ BD also has more advanced antibacterial properties and lower cytotoxic effects when compared to MTA. ${ }^{21}$ BD has high alkaline $\mathrm{pH}$ values which causes an inhibitory 
effect on microorganisms; therefore, the alkali environment, formed by $\mathrm{BD}$, provides the disinfection of surrounding hard and soft tissues. $^{22}$ In a study related to the biocompatibility of $\mathrm{BD}$, Laurent et al. ${ }^{23}$ reported that, regardless of concentration, BD did not have a cytotoxic or genotoxic effect on pulp fibroblasts; consequently, did not cause modification in the function of these cells when used as a base material or pulp capping agent. About et al. ${ }^{24}$ reached to the conclusion that BD stimulates dentin regeneration by inducing odontoblast differentiation from pulp progenitor cells in studies examining the activity of BD on activation, differentiation of pulpal progenitor cells and dentin regeneration in human dental cultures.

BD also has higher microhardness, bending resistance and compressive strength than other calcium silicate-based cements, and more similar physical property to the dentine. ${ }^{25}$ Kaup et al. ${ }^{26}$ reported a statistically significant increase in SBSs values of BD to dentin between the groups of waited 2 and 7 days, yet no statistically significant difference was apparent between the groups of waited 7 and 14 days; Jang et al. $^{27}$ assessed the hardening times of MTA, Bioaggregate and BD, and compared the compressive strengths after awaited $\mathrm{BD}$ for 1, 3 and 7 days; as a result, the groups showed similar compressive strength values which resulted in no statistically significant difference between the groups.

In the study conducted by Kaup et al. ${ }^{26}$ evaluated the SBSs of BD, ProRoot MTA, GIC and composite resins to dentin on permanent teeth; self-etch (SE) adhesive system was applied to the dentin only in the composite resin group, while no application was performed in the other groups. Samples were separated into different time groups of 2, 7 and 14 days before conducting SBS test, and stored at $37.5^{\circ} \mathrm{C}$ in $100 \%$ humidity. As a result, among all the materials tested, Pro Root MTA gave the lowest SBS values. A statistically significant increase was observed in the SBS values of BD to dentin between 2 and 7 days. Hashem et al. ${ }^{28}$ reported that the bond strength values of $\mathrm{BD}$ to composite resin at the beginning were lower in the studies that evaluated the microshear bond strength of BD groups which were kept for different durations, and these bonding values reached to the values of conventional glass ionomer cements(GICs) only 24 hours later; therefore, the research stated that BD should be allowed 2 weeks for maturation before the final restoration.

Reported that BD takes the form of a hydrated calcium silicate gel with poor physical-mechanical properties as a result of the initial hardening reaction which lasts approximately 12 minutes, and in this stage hardening occurs only on the surface. Besides, the BD maturation through the crystallization of the calcium silicate hydrate gel texture takes about two weeks; therefore, the material must take at least 2 weeks to achieve final hardening and maximum physical-mechanical properties. ${ }^{29}$ However, while considering the results of our study, no statistically significant difference on the SBS values of BFCs between BD, kept for 24 hours and 2 weeks, was found.

Cantekin and $\mathrm{Avc1}^{30}$ investigated the SBS values between the applications of methacrylate-based composite, silorane-based composite and GIC with different adhesive systems on BD and MTA, where BD samples were kept for $15 \mathrm{~min}$ and MTA samples for 96 hours at a $37^{\circ} \mathrm{C}$ and $100 \%$ humidified medium. As a result, the highest SBS values were found in methacrylate-based composite resin-BD group and the lowest SBS values were observed in the GIC-MTA group. In this study, despite that methacrylate-based composites indicated statistically significant higher SBS values in the group bonded to $\mathrm{BD}$ rather than the group bonded to MTA, other restorative materials exhibited similar SBS values when bonded to both BD and MTA. In addition, the methacrylate-based composites showed higher 
statistically significant SBSs to BD and MTA than other restorative materials. It is concluded that resin-based composites (methacrylate based) are the best choice of restoration to clinically apply on BD.

SBU, which we used in our study, has been marketed as a new type of adhesive, which is classified as Universal and can be applied with both SE and Etch-and-Rinse (ER) techniques [31]. Reported by the manufacturers that using either bonding techniques does not reduce the bonding efficiency, and these adhesive systems can also be used for the selective acidification of the enamel margins. ${ }^{32}$ From a marketing standpoint, the universal adhesives are highly innovative products that offer clinicians freedom of application for use in the ER, SE, or selective enamel etch mode without sacrificing binding effectiveness. ${ }^{33-36} \mathrm{SBU}$, used in our study, contains 10-methacryloloxydil dihydrogen phosphate (10-MDP). Universal adhesive, containing 10-MDP, may also reduce the total binding activity by also containing HEMA as a mono functional resin monomer, which competes with 10-MDP for calcium binding, reducing the amount of 10-MDP-Ca bonds. ${ }^{36}$ The 10-MDP structure contains a polymerizable methyl-methacrylate group, and a phosphate group responsible for ionic interaction with calcium. ${ }^{34}$ Theoretically, 10MDP may be considered to bind to calcium in $\mathrm{BD}$ and provide chemical bonding in addition to micromechanical binding. ${ }^{28}$ It is unknown whether a chemical bond is formed between BD and composite resin. However, it has been theoretically stated that the functional monomers (10 MDP, 4-MET) used in the adhesive systems can chemically bond to the calcium in the structure of BD, so that chemical bonding additional to micro-mechanical binding can be established. ${ }^{26-28}$ Odabas et al. ${ }^{36}$ evaluated the dentin bonding strengths of composite to BD groups, awaited for 12 minutes and 24 hours, using total-etch, 2-step SE, and 1step SE adhesive systems, which showed higher SBS values than the total-etch groups; in addition to these results, the highest SBS values were obtained with 2-step SE adhesive systems in the 24 hour period awaited groups. On a meta-analysis by Rosa et al..$^{35}$ reported that acid application in mild acidic universal adhesive agent (Single Bond Universal) did not affect dentin bonding strength, and no difference in dentin bonding strength between ER and SE applications was observed.

Hashem et ll $^{28}$ measured micro-SBSs of composites with BD, GIC and RMGIC, by using SBU adhesive system on the modes of SE and ER models after early $(0,5,20$ minutes and 24 hours) and late (2 weeks, 1 and 6 months) aging of composites. As a result, similar to our work, they reported that the application of the SBU adhesive system by SE and ER methods did not create a statistically significant difference in the micro-SBS values. A statistically significant increase in micro-SBS values was detected in the late aging groups in BD compared to early aging groups, also the highest micro-SBS values were obtained in the 24 hour group. SE adhesive systems; it can be preferred both in terms of time and in practice, since it is easy to apply.

The most common type of fracture in our study was cohesive fracture within $\mathrm{BD}$; Contrarily, the least common fracture type was adhesive fracture. Cohesive fractures in BD show that adhesion forces between compositeadhesive-BD are stronger than the cohesive forces within BD itself. El-Kalla and GarciaGodoy ${ }^{37}$ indicated that cohesive fractures occur more frequently in both dentin and restorative material may be caused by the low internal durability of the material or higher bonding strength than the durability in material.

The breakthrough, observed in our study, shows the fractures being mostly cohesive reflecting the strength of cohesive forces within the BD structure rather than the actual bonding strength between the material and adhesive resin. Declared that the stress distribution between the dentin and composite resin was not 
homogeneous due to the use of specimens with large surface area in conventional bonding strength tests, which usually results in the cohesive type failure of the material itself. ${ }^{38}$ One of the reasons for the tendency towards cohesive failure observed in our study is assumed to be this non-homogeneous stress distribution.

Flury et al. ${ }^{14}$ conducted a study using four different BFCs (Tetric Evoceram, Filtek, SDR, $\mathrm{x}$-trafil) and one conventional resin composite (Filtek supreme $\mathrm{xt}$ ) which were bonded on permanent tooth dentin in different thicknesses (2mm, 4mm and 6mm); subsequently, compared their SBS values. When the results of the study examined, the SBS value differences of BFCs between the thicknesses of $2 \mathrm{~mm}$ and $4 \mathrm{~mm}$ were not statistically significant ( $p>$ 0.05). Considering these results, when the bonding strength values of Tetric Evoceram, Filtek, SDR BFCs were evaluated in $2 \mathrm{~mm}$ and $4 \mathrm{~mm}$ of thicknesses to BD, the difference was statistically insignificant ( $p>0.05$ ) in our study, as well. Analyzing the results of our study, when connection strengths of FP BFCs in $2 \mathrm{~mm}$ to $4 \mathrm{~mm}$ were statistically compared, a significant difference was found $(\mathrm{p}<0.05)$. Our opinion is that this difference was caused by the difference in content of this BFC.

$\mathrm{BD}$, which has indication in many areas of dentistry, with improved physical properties, short curing time, easy manipulation and good biological properties, can be regarded as a good alternative material for MTA. ${ }^{39,40}$ In the direction of data obtained in our study, we came to think that the restoration of the BFC to be placed on the BD material has a positive effect on the bonding strength after awaiting for 24hour, which may increase the long-term success of the restoration. Furthermore, BFCs could be placed in the cavity with a single step applying $4 \mathrm{~mm}$ in thickness with SE technique; reducing the number of steps will be extremely valuable in Pediatric Dentistry, by also reducing the technical sensitivity, duration of application and the risk of saliva contamination especially when working with the children who can not be cooperated. This research was conducted in vitro, which does not provide a possibility to fully reflect the oral environment (occlusal stresses, blood-saliva contamination, etc.) to the study. Therefore, in order to investigate the clinically performance of the BD and BFC materials, in vitro studies must be accompanied and supported by clinical studies. In clinically, we may prefer to use BFC at a height of 4 $\mathrm{mm}$,onto BD with after 1 day of waiting time.

\section{REFERENCES}

1. Tziafas D, Smith A J, Lesot H. Designing new treatment strategies in vital pulp therapy. J Dent 2000; 28:77-92.

2. Stanley HR. Pulp capping: conserving the dental pulp--can it be done? Is it worth it? Oral Surg Oral Med Oral Pathol 1989; 68: 628-39.

3. Kopel HM. Considerations for the direct pulp capping procedure in primary teeth:a review of the literature. ASDC J Dent Child 1992; 59: 1419.

4. Aeinehchi M, Eslami B, Ghanbariha M,Saffar AS. Mineral trioxide aggregate (MTA) and calcium hydroxide as pulp-capping agents in human teeth: a preliminary report. Int Endod J 2003; 36: 225-31.

5. Aminoshariae A, Hartwell GR,Moon PC. Placement of mineral trioxide aggregate using two different techniques. J Endod 2003; 29: 67982.

6. Antunes Bortoluzzi E, Juárez Broon $\mathrm{N}$, Antonio Hungaro Duarte M, de Oliveira Demarchi AC, Monteiro Bramante C. The use of a setting accelerator and its effect on $\mathrm{pH}$ and calcium ion release of mineral trioxide aggregate and white Portland cement. J Endod 2006; 32:1194-7.

7. Camilleri J, Sorrentino F, Damidot D. Investigation of the hydration and bioactivity of radiopacified tricalcium silicate cement, Biodentine and MTA Angelus. Dent Mater 2013; 29: 580-93. 
8. Pradelle-Plasse N, Tran, XV, Colon $P$. Physico chemical properties, Biocompatibility or cytotoxic effects of dental composites.Oxford: Coxmoor Publishing Co; 2009. p.184-94.

9. Bortoluzzi EA, Broon NJ, Bramante CM, Felippe WT, Tanomaru Filho M, Esberard $\mathrm{RM}$. The influence of calcium chloride on the setting time, solubility, disintegration, and $\mathrm{pH}$ of mineral trioxide aggregate and white Portland cement with a radiopacifier. J Endod 2009; 35: 550-4.

10.Camilleri J, Grech L, Galea K, Keir D, Fenech M, Formosa L, Damidot D, Mallia B. Porosity and root dentine to material interface assessment of calcium silicate-based root-end filling materials. Clin Oral Investig 2014; 18: 1437-46.

11. Nowicka A, Lipski M, Parafiniuk M, Sporniak-TutakK, Lichota

D, Kosierkiewicz A, Kaczmarek

W, Buczkowska-Radlińska J. Response of human dental pulp capped with biodentine and mineral trioxide aggregate. J Endod 2013; 39:743-7.

12.Vidal K, Martin G, Lozano O, Salas M, Trigueros J, Aguilar G. Apical Closure in Apexification: A Review and Case Report of Apexification Treatment of an Immature Permanent Tooth with Biodentine. J Endod. 2016; 42: 730-4.

13.Moszner N, Gianasmidis A, Klapdohr S, Fischer UK, Rheinberger V. Sol-gel materials 2. Light-curing dental composites based on ormocers of cross-linking alkoxysilane methacrylates and further nanocomponents. Dent Mater 2008; 24: 851-6.

14.Flury S, Hayoz S, Peutzfeldt A, Husler J, Lussi A. Depth of cure of rezin composites: is the ISO 4049 method suitable for bulk fill materials? Dent Mater 2012; 28: 521- 528.

15.Ilie N, Bucuta S, Draenert M. Bulk-fill resin based composites: an in vitro assessment of their mechanical performance. Oper Dent 2013; 38: 618-625.
16. Yasa E, Atalayin C, Karacolak G, Sari T, Turkun LS. Intrapulpal temperature changes during curing of different bulk-fill restorative materials. Dent Mater J 2017; 26;36(5):566572.

17. Karaman E, Yazici AR, Ozgunaltay G, Dayangac B. Clinical evaluation of a nanohybrid and a flowable resin composite in non-carious cervical lesions: 24-month results. J Adhes Dent 2012; 14: 485-92.

18.Czasch $\mathrm{P}$, Ilie $\mathrm{N}$. In vitro comparison of mechanical properties and degree of cure of bulk-fill composites. Clin Oral Investig 2013; 17: 227-35.

19.El-Safty S, Silikas N, Watts DC. Creep deformation of restorative resincomposites intended for bulk-fill placement. Dent Mater 2012; 28, 928-935.

20.Moorthy A, Hogg $\quad \mathrm{CH}$, Dowling AH, Grufferty BF, Benetti AR, Fleming GJ. Cuspal deflection and microleakage in premolar teeth restored with bulk-fill flowable resinbased composite base materials. J Dent 2012; 40: 500-5.

21. Shayegan A, Jurysta C, Atash R, Petein M, Abbeele AV. Biodentine used as a pulp-capping agent in primary pig teeth. Pediatr Dent 2012; 34(7):e202-8.

22.Rathinam E, Rajasekharan S, Chitturi RT, Declercq H, Martens L, De Coster P. Gene Expression Profiling and Molecular Signaling of Various Cells in Response to Tricalcium Silicate Cements: A Systematic Review. J Endod 2016; 42: 1713-1725.

23.Laurent P, Camps J, De Meo M, Dejou J, About I. Induction of specific cell responses to a $\mathrm{Ca}(3) \mathrm{SiO}(5)$-based posterior restorative material. Dent Mater 2008; 24: 1486-94.

24. About I, Laurent P, Tecles O. Bioactivity of Biodentine a CA3SiO5-based Dentine Substitute. 2010; Oral session. IADR Congress. 25. Laurent P, Aubut V, About I. Development of a bioactive $\mathrm{Ca} 3 \mathrm{SiO} 5$ based posterior restorative material (Biodentine ${ }^{\mathrm{TM}}$ ), Biocompatibility or cytotoxic effects of dental 
composites.Oxford: Coxmoor; 2009. p.195200.

26.Kaup M, Dammann CH, Schafer E, Dammaschke T. Shear bond strength of Biodentine, ProRoot MTA, glass ionomer cement and composite resin on human dentine ex vivo. Head Face Med 2015 Apr 19;11:14.

27.Jang YE, Lee BN, Koh JT, Park YJ, Joo NE, Chang HS, Hwang IN, Oh WM, Hwang YC. Cytotoxicity and physical properties of tricalcium silicate-based endodontic materials. Restor Dent Endod 2014; 39: 89-94.

28. Hashem DF, Foxton R, Manoharan A, Watson TF, Banerjee A. The physical characteristics of resin composite-calcium silicate interface as part of a layered/laminate adhesive restoration. Dent Mater 2014; 30: 343-9.

29. Bachoo IK, Seymour D, Brunton P. A biocompatible and bioactive replacement for dentine: is this a reality? The properties and uses of a novel calcium-based cement. Br Dent $\mathbf{J}$ 2013 Jan;214(2):E5.

30.Cantekin K, Avci S. Evaluation of shear bond strength of two resin-based composites and glass ionomer cement to pure tricalcium silicate-based cement (Biodentine(R)). J Appl Oral Sci 2014; 22: 302-6.

31.Hanabusa M, Mine A, Kuboki T, Momoi Y, Van Ende A, Van Meerbeek B, De Munck J. Bonding effectiveness of a new 'multi-mode' adhesive to enamel and dentine. J Dent 2012; 40: 475-84.

32. Marchesi G, Frassetto A, Mazzoni A, Apolonio F, Diolosa M, Cadenaro M, Di Lenarda R, Pashley DH, Tay F, Breschi L. Adhesive performance of a multi-mode adhesive system: 1-year in vitro study. J Dent 2014; 42: 603-12.

33. Chen $\mathrm{C}$, Niu LN, Xie H, Zhang ZY, Zhou LQ, Jiao K, Chen JH, Pashley, DH, Tay FR. Bonding of universal adhesives to dentine--Old wine in new bottles? J Dent 2015; 43: 525-36.
34. Yoshida $\mathrm{Y}$, Yoshihara $\mathrm{K}$, Hayakawa $\mathrm{S}$, Nagaoka N, Okihara T, Matsumoto T, Minagi S, Osaka A, Van Landuyt K,Van Meerbeek B. HEMA inhibits interfacial nano-layering of the functional monomer MDP. J Dent Res 2012; 91: 1060-5.

35. Rosa WL, Piva E, Silva AF. Bond strength of universal adhesives: A systematic review and meta-analysis. J Dent 2015; 43: 765-776.

36. Odabas ME, Bani M, Tirali RE. Shear bond strengths of different adhesive systems to biodentine. ScientificWorldJournal 2013 Oct 10;2013:626103.

37.el-Kalla IH, Garcia-Godoy F. Bond strength and interfacial micromorphology of compomers in primary and permanent teeth. Int J Paediatr Dent 1998; 8: 103-14.

38.Pashley DH, Carvalho RM, Sano H, Nakajima M, Yoshiyama M, Shono $\mathrm{Y}$, Fernandes CA, Tay F. The microtensile bond test: a review. J Adhes Dent 1999; 1: 299-309.

39. Malkondu O, Karapinar Kazandag M, Kazazoglu E. A review on biodentine, a contemporary dentine replacement and repair material. Biomed Res Int 2014; 2014: 160951.

40.Aksoy S, Ünal M. Shear bond strength of universal adhesive systems to a bioactive dentin substitute (Biodentine ${ }^{\circledR}$ ) at different time intervals. Stomatological Dis Sci 2017;1:116-22.

\section{Corresponding Author}

Murat UNAL (DDS. PhD. Associate Professor)

Department of Pediatric Dentistry,

Faculty of Dentistry

Cumhuriyet University,

Sivas, Turkey

Phone : +90 5062734583

Fax : :+90 3462191237

E-mail : gmuratunal@ hotmail.com munal@cumhuriyet.edu.tr 